DOI: 10.2478/atd-2019-0001

\title{
Coping with Adversity in the Lives of Children in Foster Care
}

\author{
Viola Tamášová - Silvia Barnová*
}

Received: January 7, 2019; received in revised form: March 3, 2019; accepted: March 5, 2019

\begin{abstract}
:
Introduction: The theoretical-empirical study is based on two particular case studies of families bringing up children from institutional care. It deals with the real needs of foster families, with the foster parents' perception of fostering and their experiences from the time spent with children in foster care, about the children's behaviour in adverse situations, which the foster parents must deal with in the period of the child's adaptation to the new environment of their households. The authors accentuate the importance of communication and emotional education from the aspect of personality development of children placed into new families. These children should be prepared for moving from a known into an unknown environment. In the conclusions, the authors give several specific recommendations within the framework of semantic categories dealt with in the chapters and subchapters of the study.

Methods: The study is based on a theoretical analysis of the presented issues. For the purposes of the research, the following research methods were used:

- Content analysis of official documents (job description of social workers in foster family care).

- Case studies of two clients of the offices of Social and Legal Protection of Children and Social Curatorship in the field offices of Central Office of Labour, Social Affairs and Family in Nitra and Bratislava SelfGoverning Regions carried out in 2018.

- Logical operations - analysis, synthesis, comparison.

- Interviews with foster carers (Family 1 and Family 2) carried out throughout the whole year 2018 .
\end{abstract}

\footnotetext{
* Viola Tamášová, DTI University, Department of School Pedagogy and Psychology, Dubnica nad Váhom, Slovakia; tamasova@dti.sk

Silvia Barnová, DTI University, Department of School Pedagogy and Psychology, Dubnica nad Váhom, Slovakia; barnova@dti.sk
} 


\section{Acta Educationis Generalis \\ volume 9, 2019, issue 1}

- Generalization in semantic categories which, at the same time, are the titles of the chapters and subchapters bellow, and also in the conclusions and recommendations for foster care and the social practice.

Results: For personal development, children need relationships with others. Maternal and paternal love, and care are the basic elements of these relationships - as confirmed in the interviews with foster parents. Alongside with biological parenthood, the so-called "psychological parenthood" has an important role to play. The role of a psychological parent can be filled by the members of own (i.e. biological) family as well as by adoptive parents, foster parents, the biological parents' partners (stepmothers and stepfathers) and - under certain conditions - also by personnel in facilities of social care. Their psychological needs and the extent of their satisfaction determine what they will experience and how they will feel.

Discussion: It is important to prepare parents to accept the fact that foster parenthood is different from biological parenthood. Prospective foster parents often come to the offices of Social and Legal Protection of Children and Social Curatorship with the opinion that not even biological parents are being prepared for their parental roles. Foster parents already having biological children argue - as it follows from the interviews carried out throughout the research - that they are experienced parents and, so, they can bring up foster children as well. They do not realize that foster children bring something new that biological children have never experienced. Biological and foster parenthood are definitely not the same.

Conclusions: In the conclusions, the authors point out that children in foster care identify with their parents' values and opinions. For children who have faced significant adversity in their lives, it is beneficial if the family environment and education are harmonious. Such good conditions can have a positive impact on the children's entire future lives. In the process of adaptation, the whole network of relationships within the family must be re-structuralized, which requires well-prepared family members.

Key words: foster family, adverse life situations, family communication, tolerance, adaptation, emotional education, frustration, facilities of social care, family social work.

\section{Introduction}

Foster family care represents an important legal remedy to solve unfavourable situations in the life of children whose parents cannot ensure personal care of them due to objective reasons, have misused their parental rights, neglected their children or violated their rights. The study focuses on the issues of mutual adjustment and getting used to each other, which create a space for adaptation. The stage of adaptation is crucial in the process of developing a good relationship between the child and the parents (Rozvadský Gugová, 2018, p. 82). 


\section{Acta Educationis Generalis \\ volume 9, 2019, issue 1}

At the same time, it is one of the most demanding periods as it has a significant impact on the entire future life of the foster family.

\section{Objectives of the study}

Based on case studies in two families with children in foster care (Family 1 and Family 2), our intention was to find out about:

- the foster parents' ideas about the child when making the decision to become foster parents;

- the needs of foster families, what is important for them, how they perceive their foster parenthood and the time spent with their children, and their reactions in demanding situations that foster parents must deal with during the period of children's adaptation to the new environment of their households;

- their motivation for foster parenting, the factors influencing their decision to take a child from a facility of social care to foster family care, i.e. to their family environment;

- children's emotional attachment to the family of foster parents (including their biological children);

- the importance of emotional education from the aspect of children's personality development;

- the educational means used by parents in the process of emotional education of own and foster children and the role of communication in families.

\section{Methods}

In the study, traditional desk research methods were used in order to describe the background of the research. For the purposes of developing theoretical-empirical strategies, analysis and generalization, the following research methods were used:

- content analysis of official documents (job description of social workers in foster family care);

- case studies of selected clients of the offices of Social and Legal Protection of Children and Social Curatorship in the field offices of Central Office of Labour, Social Affairs and Family in Nitra and Bratislava Self-Governing Regions carried out in 2018;

- logical operations - analysis, synthesis, comparison, generalisation;

- interviews with applicants for foster family care realized throughout the whole year 2018.

The obtained data were generalized in semantic categories which are used in the titles of the chapters and subchapters; and some specific recommendations for families and the social practice were formulated. 


\section{Acta Educationis Generalis \\ volume 9, 2019, issue 1}

\section{Semantic categories}

\subsection{The period of adaptation in the foster family}

The time of adjustment and getting used to each other creates space for adaptation. It can take several weeks, months or even years. The period of adaptation is crucial from the aspect of building a good relationship between parents and children, and, at the same time, it is among the most demanding periods determining the whole future life of the foster family. In the case study, both foster families (F1 and F2) pointed out that, as for attachment, there were no significant differences between children placed in foster families as babies and children growing up in traditional families. Some differences can be observed after 6 months. During the first six months of children's life, i.e. in the period of adaptation, manifestations of fear and insecurity, e.g. eating disorders, problems with sleeping, chronic diarrhoea, or crying without a reason can be observed. Older children coming to foster families from a facility of social care have lost their ability to trust people as well as the relationships around them and often suffer from a lack of them (García, Aluja, \& Del Bario, 2006). Therefore, parents should be sensitive to their children's needs and try to satisfy them as it is one of the basic preconditions for gaining their children's trust.

The authors distinguish between three groups of children, including those who are being prepared for adoption or moving to foster care:

1. Children which have never developed primary attachment and have never experienced safety, security and trust.

2. Children with inadequate attachment relationships as the result of frequent changes of caregivers as children have moved from one foster family to another.

3. Traumatized children which had the opportunity to develop primary attachment in their early childhood, but experienced strong traumas (sexual abuse, physical abuse or emotional neglect) which disrupted the initial trust (Priehradná 2006; Crawford, Cohen, Chen, Anglin, \& Ehrensaft, 2009; Morrissey, 2009).

Which are the most frequently occurring problems related to foster parenthood after the initial months of living together with their foster children? Among the respondents' (F1 and F2) answers are:

- Problems with sleeping, bursts of anger, pulling hair, biting nails, head banging, tooth scratching, and thumb sucking;

- Egoism, laxity, a strong desire to possess thing, lying and thefts;

- Short attention span, insufficient motivation, passivity and weak will;

- Maladaptation, defiance and disobedience.

As our research findings - which we compared with the work of experts in the field of psychology - show that the most frequent manifestations of children's behaviour in the phase of adaptation, are the following: 


\section{Acta Educationis Generalis \\ volume 9, 2019, issue 1}

- Closing themselves and refusing behaviour. In some children, closing themselves is "only" a manifestation of self-oriented anger. Children do not know what they can expect from their new parents, they are insecure and do not trust anyone. Therefore, it is important to emphasize the children's value.

- Hiding food and swallowing. It is a mental problem. Children try to fill the chronic inner emptiness and to compensate for their not satisfied emotional needs by eating and hiding food. As Priehradná (2006) claims, it is important to react to such a situation adequately. Children need a lot of love and emotional security demonstrated in physical contact.

- Aggressive behaviour. Aggression may be the only form of emotional release for children when fear, anger or insecurity occur. It helps them keep distance from people and so, they do not need to deal with their fears and distrust. Aggressive behaviour in children can be directed against other people, themselves, or objects.

- Lying and thefts. Foster parents are usually frustrated by such a behaviour. Some children lie even when there is no reason for it. In some children, lying and thefts can be explained rather by some kind of fear or their habit for stealing than by anger or a necessity. They often cannot explain why they lie, not rarely they do so without any reason and even in situations when they cannot gain any profit from it - about their lunch, who they played with at school, etc.). First of all, parents should find out what the real motivation for lying and thefts is and then they can react appropriately.

- Weak or no eye-contact. Children which do not trust the world around them are often unable to keep eye-contact with the exception of cases when they are angry or try to manipulate people around them.

- Difficulties in developing positive relationships. Children often do not differentiate between people who are close to them and those who they do not know as there was no one who they could consider their mother or father in the past. These children have a strong need to attract the attention of strangers. Foster parents should limit the number of people taking care of children and, therefore, not to place children in kindergartens and to minimize visits especially during the first weeks, if possible.

- Disrupted relationship to objects. Children in facilities of social care do not possess anything. All the toys are common (collective ownership), no one is responsible for their damage (collective responsibility). For children, it is important to possess objects. It helps them develop their identity and responsibility as well. Foster parents should patiently build a "new" system of values.

- Loss of hygienic habits. When leaving a facility of social care and moving to a family, children are often frustrated. They subconsciously try to cope with the new situation by returning to one of the previous levels of behaviour (regression), e.g. wetting occurs. It is usually a temporary 


\section{Acta Educationis Generalis \\ volume 9, 2019, issue 1}

problem (Priehradná, 2006, García, Aluja, \& Del Bario, 2006; Madro, 2018).

In agreement with Evans (2006), the authors believe that if parents are aware of the importance of adaptation and can recognize its manifestations (fear and anxiety), they can create a positive and inclusive family environment for children.

For a better understanding of the importance of children's adjustment to the foster family environment, Matějček and Dytrych summarized their knowledge and experiences in ten points which can serve as a source of inspiration:

1. Do not be afraid to accept "foster" parenthood! The emphasis is on the word parenthood. Doing good parenthood means the acceptance of children as they are, i.e. without any prejudice and unconditionally. Psychological parenthood is more important than the biological conception of children.

2. Do not be afraid of not gaining or losing the child's love! Children consider their mother or father those people in their close environment, who treat them like their children and it does not matter who gave them birth. A mutual relationship is created by living together and sharing lives.

3. Do not be afraid of working on own development and improvement! It is true that for biological parents, it is much easier to understand their children and accept their individualities and uniqueness. Foster parents and other caretakers must learn everything from the beginning.

4. Hiding the truth in personal relationships is dangerous! The Family Law (Act No. 36/2005 on Family) promotes adoption. It provides families with external protection, but internal protection can only be ensured by the parents themselves. To do so, they must adopt the identity of foster parents and lead their children towards the acceptance of the positive identity of the adopted child.

5. Children need to know more about themselves than anyone else! It is necessary to avoid situations when the children might be shocked by information that they do not understand and which might harm the relationship between them and their foster parents. The identity of a foster or adopted child must be clear and reliable. Children in foster care must be sure of their parents' unconditional love, that they will never leave them and that they are really important for them.

6. It is not enough to tell it; it is necessary to talk about it! It is not good to wait until the children start asking questions about their biological parents; it is much better to find a good occasion and talk about the issues related to being an adoptive child. Children need to talk in order to process and accept such a situation and feel belonging. It is, for example, good to celebrate the day when the child came into the family as their second birthday, which is "the happiest day in the parents' lives."

7. The child is not from the parents' bodies but is theirs! There is no reason to have worries about the children's genetic predispositions but it is good to be 


\section{Acta Educationis Generalis \\ volume 9, 2019, issue 1}

prepared for the fact that some personality traits, the cognitive level, their inclinations and the performance of their mental functions, etc., may be partially inherited. If the parents try to understand their children, it is the first step towards success.

8. It is better to expect the worse and be surprised by the better! Parents' too high demands and expectations placed on children can be as dangerous as the parents' wishes or dreams that children should make true. They can lead to children's behaviour problems and the parents' disappointment.

According to the authors, the more concrete the foster parents', adoptive parents', or stepparents' ideas about what the children should look like, what they should achieve are, the more problems can occur in the family. So, more problems can be observed in the families of ambitious intellectuals and artists, as well as religious people obeying strict and unchangeable rules and regulations.

9. Only good things should be said about the child's biological parents! Sufficient information about the roots of children can help building their healthy identities. The existence of the biological parents should be accepted by the foster parents as well as by stepmothers and stepfathers after the divorce or death of biological parents. The role of foster parents is a bit easier as they are the children's legal guardians and take over their parents' role.

The authors of the study recommend not to expect gratefulness for saving them from danger and misery - whether in their biological families or institutional care - but become those who really love them. Foster parents should speak about the children's biological parents in a way which allows them to gradually add new details. They should not hide the truth nor lie about anything.

10. Open the family society! Foster families tend to live in isolation and to develop own protective mechanisms. It is beneficial to involve the grandparents, other relatives and friends from the very beginning. All these people should be of the same opinion and have the same attitude towards children as the foster parents do. Matějček and Dytrych (1998, p. 36), professionals in this field, accentuate that they can help the family when demanding situations occur.

Based on the authors' experiences, it can be assumed that childless married couples are more at risk as for separation than couples with children, but, at the same time, it can be observed that the risk is higher for couples with foster children compared to couples bringing up their biological children. Foster parents must work hard on themselves and they need more social support from their social environment - close family, relatives, friends but also other people around them - than other families.

The authors agree with Matej (2000) that it is important to explain the foster parents that foster parenthood and biological parenthood are not the same. As we 


\section{Acta Educationis Generalis \\ volume 9, 2019, issue 1}

found out during the interviews, foster parents-to-be visit the offices of Social and Legal Protection of Children and Social Curatorship and express their opinion that not even biological parents are being prepared for parenthood and many of them are not sufficiently skilled for the role of a parent. Foster parents, especially those which have own biological children and intend to adopt or take into foster care another child, stated that they had brought up their own children and would bring up children from facilities of social care as well, that they were experienced enough. Even though the authors believe that it is better for foster children to find home in families where there are biological children as well these children bring to the family something new, something what most children have not experienced. Biological and foster parenthood are not the same.

As well as every human being is a unique personality, every family is unique, different from the others. Some differences can be found, e.g. in the cultural level of the family (Hedge \& Davis, 2005), in the behaviour of its individual members, their habits, their households, family upbringing and the applied parenting styles (Kósová, 2015; Choate \& Schween, 2004). It is very difficult to decide which approach is optimal for children or what the best direction is. Useless strictness or a too liberal approach are not the most appropriate options; but a natural authority together with elements of freedom, democracy, mutual love and respect, are good preconditions for a harmonious family life.

\subsection{Parenting styles in foster families and their impact on children's personalities}

People are born into various social environments - into particular societies. For children's healthy emotional development, the character of their family environment and the appropriateness of the applied parenting styles are important. They have an impact on the choice of the means of emotional education and have the potential to affect children's emotional development positively or negatively.

Parental love should be a manifestation of an internal desire, based on the parents' emotional maturity, and a warm relationship to the child, which is the precondition for the development of the same feelings in children. Children need love, but many parents do not know how to express it. Some of them show their love by buying huge amounts of toys, sweets, giving children too much pocket money and by fulfilling all their wishes. The emotional development of children may be negatively influenced by manifestations of a "lack of love", such as threats, intimidation and inadequate punishment. Especially in the case of children which have spent some time in facilities of social care, such behaviour can lead to feeling inferior, to anxiety, shyness, and distrust in themselves. "Too much" love can be dangerous as well. In other cases, inconsistency in parents' attitudes, their moodiness, lack of love and serious problems between them can represent a threat to children's emotional development (Gondová, 1994; Ikhart \& Szobiová, 2018). 


\section{Acta Educationis Generalis \\ volume 9, 2019, issue 1}

In a harmonious family, parents teach their children to love by showing love. Children need to be assured that their parents love them. The parents' emotional inclination and love can be expressed by petting, caress, kindness, smile, but also by gestures, mimes, and eye expression. It is very important to talk about the children's problems and to try to answer their questions. Leisure time should be spent by joint activities, playing games, by going for long walks and on trips together. So, children learn to build positive relationships with others, experience fellowship, cooperation, sympathy, and empathy from their early childhood (Del Barrio, Aluja, \& García, 2004). It is something they might have never experienced before.

Tamášová (2007, p. 27) claims that “from the aspect of children's development, family has an important role to play - especially from the point of view of their emotional development. Besides satisfying their biological needs, social contacts between parents and children are built, mutual interaction and emotional bonds are developed. Families give children the feeling of security, safety, family background and stay with them throughout their whole life. These values are important from the aspect of family climate."

All children go through the same stages of development but the differences in their physical, emotional and the overall personal development are given by the specifics of individual children. The basic preconditions for successful education are love, a peaceful and harmonious environment, the presence of both parents, consistency between family and school education, positive role models, patience, an established daily routine and requirements corresponding with the children's abilities.

Within emotional education, children learn most from their parents' behaviour. They want to be like their parents - whether biological or not - and, therefore, they imitate not only their positive, but also their negative behaviour patterns and conduct. In this context, Gondová (1998, p. 18) distinguishes between the following means of emotional education:

- games provide children with an opportunity to develop positive emotions, a positive approach towards people, objects and work;

- helping at home (housework, gardening, tiding up in the children's bedroom, personal hygiene, etc.);

- aesthetic education (painting, singing, fairy-tales, poems, illustrations in books, visiting cultural events);

- audio-visual devices (films, theatre, TV, radio, Internet) evoking aesthetic emotional experiences in children;

- explanation, discussion, narration and instruction (together with other means and methods of education);

- assessment (rewards, appraisal, punishment) which is important from the aspect of children's emotional development.

If children feel to be loved by parents, they are able to accept criticism and punishment as well. In this context, after children try to fix their mistakes, the 


\section{Acta Educationis Generalis \\ volume 9, 2019, issue 1}

ability to forgive has a big role to play. Thanks to it, the relationships disturbed by inappropriate behaviour can be fixed and children can feel escape, release and gratefulness again. From the aspect of education, it is important to analyse the forms and the character of family education. Tamášová $(2007$, p. 13) declares that "sensitive communication and mutual acceptance of others' personalities are important in the everyday interaction between children and their parents; and the principle of humanity should be applied."

Depending on the extent to which parents are able to preserve the balance between emotionality and rationality, as well as between the children's and their needs and requirements, they select from a scale of suitable and inappropriate parenting styles. Zelina (1994) considers inappropriate such a style of education in which "low demands, strictness, emotional coldness, minimal creativity and external motivation (coercion and manipulation) are applied by parents or teachers. A relatively good parenting style can be characterized as demanding, non-directive, emotional, creative and using internal motivation (i.e. it is children themselves who want to do something - leading towards independence)", so, parents should consider their parenting style. According to Holúbek (1995a, p. 14), an optimal parenting style can be characterized by love and acceptance, empathy, adequate requirements, efficient control and fair assessment of performance. Especially children in foster care are very sensitive to such parental manifestations.

From the aspect of successful development, the first year of life is very important, when deep emotional bonds are formed. Mothers have a significant role in this process, they cuddle and caress their children, and smile at them. It is pleasant for children and, so, a bond between the mother and the child is being built. Those children which were given up by their mothers, have not experienced such a good feeling. It was confirmed during the interviews with our respondents as well.

Besides physical contact, fairy tales have a strong impact on children's emotional development. They fill them with joy and, at the same time, develop their moral values. Children are happy if the good wins over the evil. Fairy-tales have the biggest impact on children when they are read or told by their parents or grandparents. From the educational aspect, avoiding drastic or scary stories and cartoons is recommended. Telling children stories and reading books in the nature help develop their emotional life. Not only the perception of the beauty of the nature, but also an active involvement of children into activities - e.g. planting and watering flowers, feeding birds, etc. - is important. Good relationships between family members form the basis for successful emotional education. From this aspect, various games and sports providing children with opportunities to experience positive emotions and, at the same time, a positive relationship between the parents and children are appropriate. Various family events and celebrations, participation in regional festivals and galas contribute to children's emotional development as well. Regular and intensive 


\section{Acta Educationis Generalis \\ volume 9, 2019, issue 1}

communication with children, talking about their activities from the previous day with an emphasis placed on their feelings and experiences are among the means by which children should be lead towards the acceptance of the feelings of others, sympathy and willingness to help. They may be quite unknown to foster children but they can contribute to their emotional maturity. Holúbek (1995b, p. 14) and Rostańská (2012) accentuate that children have an easier access to their parents' inner world if the communication between them is good, and thus, their empathy is more developed.

Kósová (2015) states that children's emotional development may be promoted by their parents in their leisure time by means of appropriate activities and an active lifestyle. It requires children's parents to spend their leisure time actively with their children as soon as at pre-school age, try to discover their interests and to do various activities together. It is generally accepted that negative emotions such as hatred, cynicism, cruelty, falsehood, vulgarity, bullying - even in the case of gifted children (Škrabánková \& Martínková, 2018) and delinquency are often the results of the impact of negative role models, as well as the Internet, inappropriate films and literature, and other media. Therefore, the parents' duty is to protect their children against such influences because children, due to their age and a lack of experiences, are not able to distinguish between positive and negative role models. It is important to lead them towards a critical approach in the process of selecting role models. It is an especially serious issue in the case of children from facilities of social care as they do not have experiences with a relaxed family environment and they might not have had positive role models around them.

\subsection{Tolerance and manifestations of coping with adverse situations}

The life of every individual is the result of many factors, regularities and also coincidences. Their genetic predispositions, the family in which they started learning about the world and who they live with, have an impact on how they will cope with adversity and deal with various situations in the future. The potentials and the experiences with which children enter their lives are determined by their family.

As well as knowledge and experiences gained in the primary family can be positive, healthy and mobilizing, they can be negative and having a negative impact on the future lives of children, too. It does not matter if it is a biological, adoptive or a foster family, if one of the parents passed away, left the family or the parents are divorced, whether it is a mixed or completed family, in which there are biological as well as foster children. Each of these forms of families have its specific problems, but self-respect, communication and obeying rules are among their unifying features.

In her paper, Lauková (2007, p. 5) claims that children which have experienced several demanding and frustrating situations, need well-balanced parents who are emotionally strong, with a high self-esteem, who like each other and show 


\section{Acta Educationis Generalis \\ volume 9, 2019, issue 1}

mutual respect. A marital crisis in the family is a signal of imbalance and instability. The married couple can experience feelings of loneliness, sadness, anger, jealousy, feelings of guilt and remorse. As a result, their self-esteem is law and they have problems to communicate with each other. If that is the case, the marital crisis of such a childless couple cannot be solved by taking a child into foster care.

It is a big change when a new child comes into a family and it is not possible to be sufficiently prepared. It brings changes in the entire system of the family, new relationships must be developed and new rules introduced. Things are not predictable anymore; new feelings, ideas, reactions and expectations occur. Such a change affects also the biological children in the family, for which, a new child in the family can evoke feelings of loss of security and stability. Biological children may be jealous until they find out that they are irreplaceable in the hearts of their parents. Their parents must create such conditions, in which children can preserve a high level of self-esteem. Everyday rituals bringing positive experiences, such as joint discussions, games, physical contact, appraisal and recognition, sufficient amount of time, and patience are the tools which can help parents in this process. According to Lauková (2007), "parents bear full responsibility for their actions and behaviour in the process of bringing up their children. Education is the most difficult thing in the world."

When taking a child into foster care, the age of the child plays a significant role. Foster parents possess the right for complex information about the origin of the children, and about their physical and mental health as well as their legal status. Taking a child into a family should be considered sensitively, as being emphasized by our respondents from F1 and F2, who went through a long period of thorough consideration and preparation. It is important to prevent the possible collision if the children have to go back to institutional care. In the case of older children, their will and opinions must be considered. Children should want to move to the family.

Schavel et al. agree with Roháček a Matej, who declare that "children who have spent several years in facilities of social care, get used to their environments and some of them refuse to leave and to move to families. The family environment represents something new, unnatural and unknown to them. The children's needs and requirements should be considered and respected." (Roháček \& Matej, 2005; as cited in Schavel et al., 2006, p. 66)

\subsection{The period of mutual adaptation within the family}

After children come to a family, the period of adaptation begins. During this phase, building a new structure of the whole network of relationships within the family takes place. Every family member builds his/her own personal relationship with the new child as well as the child needs to develop relationships with every family member. The length of this period may vary depending on the child's life history, the length of time spent in a neglecting 


\section{Acta Educationis Generalis \\ volume 9, 2019, issue 1}

family or in institutional care, and the extent of deprivation. The development of the relationship between siblings can represent a problem as well - the biological children of the foster parents may be jealous. It depends on the readiness of the family as a whole, their ability to let the children feel being loved and accepted. The aim of this phase is a peaceful development of an emotional attachment between the children and their foster parents. As stated by Kósová (2015), these relationships form the basis for the creation of future relationships.

Other problems can arise in the context of the child's transition from the family into the new environment of a kindergarten or school. For most children, such a change brings higher demands and some of them are not able to cope with the new situation. Therefore, in such cases, psychologists often recommend foster families to postpone the children's school attendance for one or two years. So, children are given time to catch up with their peers and to develop their communication skills, which are among the factors having a significant impact on students' academic achievement. As pointed out by Hanuliaková and Barnová (2015), and Porubčanová (2015), even in such cases, school attendance with all its expectations, duties and the demanding process of integration into the collective of classmates, are sources of stress and adversity. It often happens that foster families need counselling and a high quality cooperation between the parents, the school and a psychologist to cope with the occurring problems (Schavel \& Drexlerová, 2006).

In the process of adaptation and adjustment to the new family environment and accepting parents, as well as other family members, families often need help from professionals. Such form of support is important especially in the phase of adaptation. Based on the knowledge gained from the realized case studies, the authors of the paper claim that many foster parents are aware of the risks which foster parenthood brings. At the beginning, they were anxious, insecure and full of expectations, but their motivation was very strong. As for the issues of foster care, the importance of consistency between parents was proven. It is very important that both parents fully agree with taking a child into foster care (if the parent-to-be is not a single person). It is insufficient if only one of the partners makes the decision and the other one only accepts it. Children need, expect and desire love, attention and time from both the partners - their parents.

Many foster parents, which decided to welcome a child in their own family environment, must deal with various problems related to parenthood. Our respondents had worries about bringing up children of someone else, about the issues of the child's genetic predispositions, and the process of the identity development of a child which is not their biological child. They had to decide on whether to accept handicapped, disabled or emotionally deprived children; eventually, how to deal with such a situation.

The practice has shown that only those who are able to accept their identity of foster parents - which is different from the identity of biological parents but is equally valuable - can help their children overcome all the obstacles in the 


\section{Acta Educationis Generalis \\ volume 9, 2019, issue 1}

process of building the identity of a foster child. Without such an approach, the children, as well as the mutual parent-child relationship are endangered and there is a threat that the children will be unprepared to process the truth and face the reality, they will be informed about their status by others, at the wrong time and inappropriately.

Parents cannot predict how their foster children will develop in their family and how successful they will be. They cannot even predict it in the case of their own biological children. Children in foster families have different genetic predispositions and it sometimes happens that the results of the combination of negative genetic factors, emotional frustration and other unfavourable circumstances emerge during pubescence in the form of serious behaviour issues accompanied by discordant development and personality disorders. In exceptional cases, foster parents are not able to bring up children under such circumstances and they must go back to institutional care. Fortunately, such cases are rather rare.

Pubescence is a key period from the point of view of building the identity of the children in foster care, which is necessarily related to searching for their roots. One of the tasks of foster parents is to lead these children, help them overcome all the obstacles in the process of searching, to help them integrate their past into the presence and give them hope in a better future.

\subsection{Conditions and principles having an impact on successful family education - relationships and activities}

For children's personality development, good relationships are necessary. The most important elements in these relationships are parental love (Cimprichová Gežová, 2015) and care, which was proven during the interviews with foster parents. Alongside with biological parenthood, we must mention "psychological parenthood" as well. Biological parents, but also other people taking care of the child - adoptive parents, foster parents, the partners of biological parents (stepmothers and stepfathers) can fill the role of psychological parents and under certain circumstances - also people working in facilities of social care. The absence of a parental model may lead to deprivation while if parents lack sufficient parenting skills, it comes to sub-deprivation, e.g. in the case of parents - alcoholics (Winkler et al., 2003; Lahe, 2011; Rozvadský Gugová \& Heretik, 2011).

Children's psychological needs and their satisfaction are among important predictors of what and how the children will experience. Therefore, everyone, including foster parents, should realize that:

- Upbringing should be a manifestation of acceptance, and realized in favour of the child being brought up.

- Upbringing, in order to be successful, should become or, if necessary, be transformed into unconditional love. 


\section{Acta Educationis Generalis \\ volume 9, 2019, issue 1}

- Clear goals of upbringing, comprehensible and acceptable rules accompanied by a friendly approach during the process of their application and realization, are the way to their hearts (Potočárová, 1999a, p. 10).

In the journal Don Bosco, in his paper, Bruno Ferrara (as cited in Potočárová, $1999 \mathrm{~b}$ ) offers several practical recommendations related to meeting the goals of upbringing. Responsible family upbringing should include several tasks: help children trust themselves, teach them respect and honesty, to involve children in housework, fill them with enthusiasm, lead them towards sensitivity and sympathy, teach them how to deal with adversity and failure, to show children how to negotiate, encourage their creativity, laugh with them and to take the path of hope with them.

Upbringing is based on social learning, the ability to observe, imitate, identify with role models, and practicing. In this process, three basic phases of "instilling" - which, later on, determine a person's approach to all life values come into play:

a) instilling in early childhood, in which the mother-child relationship is decisive,

b) the second phase in which the mutual relationship between parents becomes a behaviour model for the child's future life,

c) instilling a holistic picture of the real world by means of the applied parenting style.

The family as such needs a meaningful orientation. In a healthy family, every family member should have his/her own role and tasks. Children need to develop their value orientation, find meaningful connections to what is surrounding them and activities in which they can engage their creative powers. Parents' main duty is to take care about their children (Lawrence, Carlson, \& Egeland, 2006), but another important task is to educate them and lead them to activities evoking positive and emotionally rich experiences. One of the ways of achieving it lies in the development of children's interests, especially at a younger school-age.

\subsection{Efficient means of education}

The most efficient means of education is providing children with positive role models. If the parents spend their free time meaningfully, their children usually follow them. A face-to-face contact, time spent together, joint activities, discussions about current events or books, and mutual exchange of experiences enrich the cognitive, emotional and volitional aspects of children's personalities. Joint leisure time activities of all family members can significantly contribute to transforming it to what it is supposed to be - an intimate community of love and life, the mediator of values for children's future lives.

The age specifics of pubescents and adolescents are a frequent reason of failure and a source of misunderstandings in upbringing and education. Taking over the responsibility for own behaviour and actions is one of the most serious issues at 


\section{Acta Educationis Generalis \\ volume 9, 2019, issue 1}

this stage of life. Peer relationships belong to the most significant factors in the process of youth's personality development. Campbell (as cited in Potočárová, $1999 \mathrm{~b}$, p. 10). deals with the specific difficulties occurring in the field of communication and outlines the importance of unconditional love, fulfilling the deepest emotional needs by eye-contact, touch, attention and the transition from being controlled by parents to self-control within it.

The parent's task is to create a family environment characterized by love, behavioural rules, clear limits and consequences for children. Parents teach their children, explain them how to act and behave, they form their proper attitudes and habits. The parents' duty is to ensure that their children follow the established daily routine, by which they promote their healthy physical development and also their sense of punctuality, discipline and order.

Prekopová (as cited in Kerekešová, 2007, p. 12) considers developing attachment and satisfying children's basic need for safety the most important factors of personality development. Without an attachment, later detachment is impossible. Only if children gain the trust of their closest ones, they can trust other people and develop self-confidence. Only if they receive love, they can give love to others. If they can observe decisiveness in their parents, one day, they will be able to develop own attitudes and to show them to others, too (Mareš, 2017). Children in foster care possess the right to get such an opportunity.

\section{Conclusions}

Children's experiences from the primary family may be positive, healthy and mobilizing, but they may also be negative, having a negative impact on the children's entire future life. Each form of families (complete, incomplete, divorced, step families, adoptive or foster families) has its own specific problems and opportunities, but the same forces, communication and rules are characteristic for them. Frequent communication regarding the needs and feelings is important as children who have had to face adversity and frustrating situations need well-balanced, emotionally strong parents with a high selfesteem who are not afraid to show respect.

Having a new family member is associated with big changes in the family system, new relationships are being developed and new rules introduced. Things are not predictable anymore, the feelings, ideas, reactions and expectations are different as well. These changes have an impact on the foster parents' biological children, too, as they may lose their safety and stability. A daily routine based on positive experiences, talks, reading fairy-tales, games, caress, appreciation and appraisal, sufficient time spent together, and patience are among the means which can help foster parents in this challenging period. During this phase of mutual adaptation, children are expected to identify with the family values, the attitudes and the opinions of the foster parents (Škoviera, 2007). A harmonious family environment is especially important in the life of children with adversity 


\section{Acta Educationis Generalis \\ volume 9, 2019, issue 1}

in their previous lives (Better care network, 2013). In this phase, the entire family network of relationships must be re-structured. The aim of this period is to build such an attachment between children and parents that they have not experienced before. This relationship forms the basis which can have a positive or negative impact on their entire future existence.

Appropriate upbringing in families requires parents to be consistent, setting clear rules, and leading children towards independent decision making. Children growing up in such an environment are happy, they have a friendly, intimate relationship with their parents, they are self-confident, can control their behaviour, even if it is a foster family.

The importance of adaptation lies in mutual adjustment and getting used to each other. It can be considered one of the preconditions for living together. As the authors of the study emphasize, personal, open and sincere communication, feeling closeness and an interest in children's future lives are very important factors leading to mutual acceptance and tolerance. It is definitely not a short and easy path. The life of every individual is the result of many factors, regularities and coincidences. It is influenced by what the individuals were born with, e.g. genetic predispositions, by the family they were born into, who they have lived with, by their ability to overcome adversity and solve various situations. Most children live in their biological families, some in foster families and those determine their experiences and potentials when entering their adult lives.

\section{References}

Act No. 305/2005 on Social and Legal Protection of Children and Social Curatorship.

Act No. 36/2005 on Family and on Amendment of Some Other Acts.

Better Care Network. (2013). Transforming services for children without parents: A decade of EU Daphne projects in collaboration with the WHO Regional Office for Europe. Retrieved from http://www.bettercarenetwork. org/library/the-continuum-of-care/residentialcare/united-kingdom-a-decade -of-european-union-eu-daphne-projects-incollaboration-with-the-worldhealth.

Cimprichová Gežová, K. (2015). Fathers' and mothers' roles and their particularities in raising children. Acta Technologica Dubnicae, 5(1), 45-50. doi 10.1515/atd-2015-0032

Crawford, T. N., Cohen P. R., Chen, H., Anglin, D. M., \& Ehrensaft, M. (2009). Early maternal separation and the trajectory of borderline personality disorder symptoms. Development and Psychopathology, 21(3),1013-1030. doi: 10.1017/S0954579409000546

Del Barrio, V., Aluja, A., \& Garcia, L. (2004). Relationship between empathy and the Big Five personality traits in a sample of Spanish 


\section{Acta Educationis Generalis \\ volume 9, 2019, issue 1}

adolescents. Social Behavior and Personality: An International Journal, 32(7), 677-681. doi: 10.2224/sbp.2004.32.7.677

Evans, G. W, (2006). Child development and the physical environment. Annual Review of Psychology, 57, 423-451. doi:10.1146/annurev.psych.57.102904. 190057

García, L. F., Aluja, A., \& Del Barrio, V. (2006). Effects of personality, rearing styles and social values on adolescents' socialisation process. Personality and Individual Differences, 40(8), 1671-1682.

Gondová, M. (1994). Bez citovej výchovy je rodinná výchova neúplná. Rodina a škola, 41(7), 18-19.

Hanuliaková, J., \& Barnová, S. (2015). Positive school climate (A theoretical empirical conspectus). Acta Technologica Dubnicae, 5(1), 68-73. doi:10.1515/atd-2015-003

Hedge, M. N., \& Davis, D. (2005). Multicultural issues in clinical practicum. In M. N. Hedge \& D. Davis, Clinical Methods and Practicum in SpeechLanguage Pathology (pp. 191-218). CliftonPark: Thomson Delmar Learning.

Holúbek, J. (1995a). Citová výchova v škole a v rodine. Rodina a škola, 42(10), 14-15.

Holúbek, J. (1995b). Výchova disciplinovaného diet’ata. Rodina a škola, 42(3), 14-15.

Choate, J. S., \& SCHVEEN, D. C. (2004). Special needs of diverse learners. In J. S. Choate (Ed.), Succesful inclusive teaching. Boston: Pearson education.

Ikhart, P., \& Szobiová, E. (2018). Parenting styles and mental health of adolescents. In E. Gajdošová et al. (Eds.), Duševné zdravie a welbeing virtuálnej generácie (pp. 64-78). Bratislava: Ipčko.

Kerekešová, M. (2007). Pevne objímat' majú rodičia, nie terapeut. Nebyt' sám, 4(1), 12.

Kósová, T. (2015). Sociálno-výchovná starostlivost' rodiny a mimorodinného života (diploma thesis). Dubnica nad Váhom: DTI University.

Lahe, D. (2011). Research on abouse and violence against the elderly in a family setting. In Acta Technologica Dubnicae, 1(2), 16-28. doi: 10.1515/atd2015-0042

Lauková, E. (2007). Komunikácia o potrebách aj pocitoch je dôležitá. Nebyt' sám. 4(3), 4-5.

Lawrence, C. R., Carlson, E. A., \& Egeland, B. (2006). The impact of foster care on development. Development and Psychopathology, 18(1), 57-76. doi: 10. 1017/S0954579406060044

Madro, M. (2018). Possibilities of psychological intervention on social networks. Acta Educationis Generalis, 8(3), 35-49. doi: 10.2478/atd-20180016

Mareš, J. (2017). Prosocial behavior education in children. Acta Educationis Generalis, 7(2), 7-16. doi: 10.1515/atd-2017-0009 


\section{Acta Educationis Generalis \\ volume 9, 2019, issue 1}

Matej, V. et al. (2000). Profesionálny rodič, alebo gul'atá kocka. Sprievodca profesionálnou náhradnou výchovou v rodine. Bratislava: OZN.

Matějček, Z., \& Dytrych, Z. (1998). Desatero pro náhradní rodiče. Náhradní rodinná péče, 2, 35-36.

Morrissey, T. W. (2009). Multiple child-care arrangements and young children's behavioral outcomes. Child Development, 80(1), 59-76. doi: 10.1111/j. 1467-8624.2008.01246.x

Porubčanová, D. (2015). Emócie "uvarené" v škole. In Kuchárska kniha pre život alebo Cesty edukácie pre život (pp. 302-315). Dubnica nad Váhom: DTI.

Potočárová, M. (1999a). Čo ovplyvňuje úspešnú výchovu v rodine. Rodina a škola, 47(3), 10.

Potočárová, M. (1999b). Rezervované rodičom a ich dospievajúcim det’om. Rodina a škola, 47(6), 10.

Priehradná, D. (2006). Adaptácia - radost' a bolest'. Nebyt' sám, 3(1), 6-18.

Roháček, M., Priehradná, D., Matejová, R., \& Matej, V. (1998). Zvykáme si jeden na druhého alebo nová náhradná rodina v procese adaptácie. Bratislava: OZN.

Roháček, M., \& Matej, V. (2005). Hladáme rodičov, ale aj opustené deti potrebujú rodinu. Bratislava: OZN.

Rostańska, E. (2012). Conversation between child and adults as educational experience. Acta Technologica Dubnicae, 2(2), 52-56. doi: 10.1515/atd2015-0060

Rozvadský Gugová, G. (2018). Styles of attachment determined by the Slovak version of sEMBU. Acta Educationis Generalis, 8(2), 82-88. doi: 10.2478/atd-2018-0014

Rozvadský Gugová, G., \& Heretik, A. (2011). Gender differences in attachment styles using sersion of the Experiences in Close Relationships - Revised (ECR-R). Acta Technologica Dubnicae,1(2), 29-36. doi: 10.1515/atd-20150043

Schavel, M., \& Drexlerová, B. (2006). Niekol'ko poznámok k sociálnemu poradenstvu v oblasti náhradnej rodinnej starostlivosti. Sociální práce, 1 , 64-70.

Škrabánková, J., \& Martínková, M. (2018). Giftedness as a possible risk of bullying. Acta Educationis Generalis, 8(3), 69-93. doi: 10.2478/atd-20180018.

Škoviera, A., (2007). Trendy náhradnej výchovy. Bratislava: Petrus.

Tamášová, V. (2007). Teória a prax rodinnej edukácie ( $2^{\text {nd }}$ edition). Bratislava: AXIMA.

Winkler, J., \& Šporcrová, I. (2003). Potřeby dítěte a náhradní výchovní péče. Sociálni práce/ Sociálna práca, 21, 54-70.

Zelina, M. (1994). Výchovné štýly. Rodina a škola, 41(8), 7. 